\title{
Defining Work Intensification through Profession-Specific Job Demands
}

\author{
W. A. M. S. U. Gunawardena \\ Imperial Institute of Higher Education, Colombo, Sri Lanka \\ Email: su.gunawardena@gmail.com
}

How to cite this paper: Gunawardena, W.A.M.S.U. (2019) Defining Work Intensification through Profession-Specific Job Demands. Journal of Human Resource and Sustainability Studies, 7, 349-359. https://doi.org/10.4236/jhrss.2019.73022

Received: June 6, 2019

Accepted: July 5, 2019

Published: July 8, 2019

Copyright $\odot 2019$ by author(s) and Scientific Research Publishing Inc. This work is licensed under the Creative Commons Attribution International License (CC BY 4.0).

http://creativecommons.org/licenses/by/4.0/

(c) (i) Open Access

\begin{abstract}
Work-related stress has escalated progressively over the past few decades that affects both health and wellbeing of the employee and productivity of the organisation. Work-related stress has become one of the most common compensated illness in many countries around the world. Therefore, there is a growing international research interest to identify how employees experience stress and specific job-related triggers of stress, which in turn helps to create employee friendly policies and conducive organizational cultures. In working environments several job characteristics have been suggested to influence workers' well-being and functioning negatively. Job demands-resource literature suggests that these job demands may lead to job burnout and health impairment process of employees. A significant body of literature is available on work-related stress, job demands and burnout. However, there is limited research on occupation-specific job demands and its effects. This study explores job demands and its effects on judicial officers in Sri Lanka. Qualitative methodology was deployed, and fifty-four semi-structured, in-depth interviews were conducted with judicial officers in Sri Lanka. Key findings included judges in Sri Lanka experienced excessive job stress stemming from profession-specific job demands such as judicial overload, political influence, and interpersonal conflict between lawyers and judges, social isolation and influence of gruesome evidence.
\end{abstract}

\section{Keywords}

Job Demands, Occupation-Specific Demands, Judicial Officers

\section{Introduction}

This paper examines the work stressors of judicial officers in Sri Lanka. Sri Lankan judges perform their duties under immense stress generated by sources such as political influence, unmanageable workloads and a lack of transparency in 
promotion procedures, which make them susceptible to higher levels of job-related stress. The role of a judge has a substantial societal impact and it is important that researchers understand the potential sources of stress and its consequences on the judicial occupation to ensure that justice is delivered in an effective and rational manner. The adoption of job demands-resource framework is useful for understanding the stressors experienced by judges in Sri Lanka in a systematic and theoretical manner. This study explores how judicial officers experience job stress and also seeks to contribute to job demands-resource theory.

Job strain (burnout) arises where various types of work demands exceed the person's capacity and capability to cope. Job demands and burnout has been researched among various occupational groups such as teachers, prison officers, health care professionals, managerial level employees, call centre employees and blue-collar employees [1] [2] [3]. However, job demands, and its effects remain under-researched theoretically and empirically and have not been applied to either judicial officers or an Asian country context such as Sri Lanka. This study explores how judicial officers in Sri Lanka experience job demands and its effects. Judicial officers belong to a professional category that is highly exposed and vulnerable to occupational stress [4].

The stress levels that judges incur can also negatively affect the way they handle evidence and make decisions. Eventually, it could lead to injustices for the parties involved, which has important implications for the integrity of the entire justice system [5]. Most of the job stress studies have focused on isolated factors such as violence, safety concerns and social isolation [5] [6] [7]. An application of job demands, and resource theory would assist in understanding the effects of these potential sources of stress on judges in a systematic and theoretical manner.

The majority of job demands studies have been conducted in western context and few studies have focused on judges in Asian context. This study encompasses a context-specific contribution to the job demands and job stress literature by conducting the study in an Asian country (Sri Lanka). This study explores how job demands are experienced by judicial officers in Sri Lanka.

The paper structured as follows; the first section provides a literature review of job demands-job resources theory; second provides the context and methodology for the study and third reviews empirical findings and fourth section provides a discussion and conclusion.

\section{Literature Review}

The job demands and job resource concept rose due to an inadequacy of previous research which was considered too simplistic [8]. The JD-R model originates from the demand-control-model (DCM; by Karasek in 1979) and the effort-reward imbalance model (ERI; by Siefrist in 1996). The underpinning assumption of both the DCM and the ERI model is that when certain job resources are absent (job control in the DCM and salary, esteem, rewards, career oppor- 
tunities in the ERI) job demands particularly lead to job strain and to burnout in the extreme case. The both models were conceptually criticised due to its simplicity and inability to capture the complexity of work environments [8]. This failure has instituted the starting point of the job demand and resources model. JD-R model contains the assumption that whereas every job may have its own risk factors associated with job stress and these factors can be categorised into job demands and job resources [9]. Accordingly, researchers sought to establish an all-encompassing model that may be applied to various occupational settings.

Job demands are physical, psychological and social aspects of the job that require sustained physical and/or psychological efforts. For example, work pressure, emotionally demanding client interactions. Therefore, job demands are associated with certain psychological costs (depression, anxiety, nervousness, burnout) and physiological costs (high blood pressure, heart disease, insomnia) [10]. Job resources refer to physical, psychological and social factors of the job which enable goal attainment and foster personal growth. It consists of social support, opportunities for professional development, performance feedback etc. [11]. For the purpose of this paper, focus is on job demands and job burnout.

Job strain arises where various types of work demands exceed the person's capacity and capability to cope. The job demands have been researched in various countries including Germany, Finland, Turkey, Netherlands, Spain and South Africa. It has also been tested among various occupational groups such as teachers, prison officers, health care professionals, managerial level employees, call centre employees and blue-collar employees [8] [12] [13] [14]. However, the job demands, and burnout remains under researched theoretically and empirically and has not been applied to either judicial officers or an Asian country context such as Sri Lanka. This study explores how judicial officers in Sri Lanka experience profession-specific job demands.

\section{Methodology}

Qualitative data was collected by conducting fifty-four, in-depth, semi-structured, face to face interviews with judicial officers in Sri Lanka. Interviews were conducted with thirty-one female and twenty-three male judicial officers with work experience ranging from 8 years to 35 years in the judiciary and the majority of the participants were career judges and some were joined from the attorney general's department. Interviews lasted between one hour to one and half hours. The participants were from the Magistrate courts, District courts, High courts, Court of Appeal and Supreme court. Access to the judiciary in Sri Lanka was provided by the memorandum of understanding signed between Postgraduate Institute of Management in Sri Lanka and Ministry of Education with the motive of broadening research access to public service.

Case study approach was adopted to answer the research question of "how judicial officers experience job demands?". All interviews were digitally recorded. Majority of the interviews were conducted in English and the interviews 
conducted in Sinhalese were translated into English. NVivo was used to code transcribed interviews. The thematic approach (six step process) was used to capture themes within coded data [15].

\section{Empirical Findings}

This section presents the finding of the study.

\subsection{Judicial Overload}

Judicial overload was a common issue experienced by the judicial officers in Sri Lanka. Forty six out of fifty-four judicial officers mentioned that work overload is a major stressor. There is a wide array of duties such as handling administration duties in the courts, reviewing administrative duties, writing judgements and orders, writing reports to ministry about the court work on weekly and monthly basis. Writing judgements is one of the crucial responsibilities of a judge. Judge should have a conducive environment to write judgements. But with the increasing workloads judges have raised concerns of not having time during the working hours to write judgements. Furthermore, Mental exhaustion they experience after presiding the bench for longer hours also hinder the ability of writing judgements. A participant stated:

"I preside till $4.00 \mathrm{pm}$, after I get down from the bench, we are bombarded with administration work. we have heaps of documents to review and sign (approve). After we go home only, I start working on judgements. It goes on till 1.00 or $2.00 \mathrm{am}$. When I start writing judgement need to finish it at a stretch. Very difficult to write judgements after-bench hours. It is strenuous..." (High court judge, 28 years).

Backlog of unheard cases is another contributing factor for work overload. Judges mentioned that some partition (land matters) and murder cases are 15-25 years old. Excessive workload leads to a difficult working pace and officers taking short breaks or none. Judicial officers mentioned that they think many times before taking a leave as it leads to an accumulation of work. Moreover, they mentioned that tight schedules in courts refrain them from having daily breaks as well. A participant stated:

"According to new circulars we should stay on the bench from 9.30am to $4.00 \mathrm{pm}$ so we have only 30 minutes of a lunch break..." (High court judge, 17 years).

Judicial officers also revealed that unrealistic targets such as newly imposed rule of the number of judgements completed within a year and increased bench time aggravates work pressure.

\subsection{Political Influence}

Political influences on the judiciary are subtle and difficult phenomenon to detect. Political pressure on judicial decisions undermines judicial independence and the sovereignty of the law [16]. Furthermore, these influences may hinder 
the ability of judicial officers to exercise their professional duties freely [16] [17].

The serious degradation of the independence and impartiality of the Sri Lankan judiciary as a result of pressure from successive governments has been widely noted inside and outside the country. Issues such as politicization of appointment process for the superior judiciary, the politicization of the Attorney-General's office in recent years, unfair removal of former Chief Justice from office have been extensively highlighted in international platforms [18] [19] [20]. Judges have revealed that politicians and higher government officials attempt to influence judicial decisions. A participant stated:

"Presidents' secretary wanted to know the final judgement of one of the cases. That case is one of his relatives. He wanted to discuss the final decision with me..." (High court judge, 27 years).

Judges can expect retribution when they do not entertain the requests of politicians and higher officials. It was revealed that if they refuse the orders and requests of politicians, they expect to suffer the consequences that can involve sudden transfers, transfers to rural areas or the withholding of promotions. A participant stated:

"Once when I did not entertain a request of a politician, I was transferred to another station without informing me, but it was the headline of one of the leading newspapers" (Magistrate, 12 years).

Thirty nine out of fifty-four judges mentioned that they have experienced political interferences during their tenure. Magistrate court and high court judicial officers are more vulnerable to political influences compared to district court judges due to the nature of the cases. Because magistrates and high court judges are presiding over criminal cases. Supreme court judges are highly susceptible to inordinate influence of executive of the country than Court of Appeal judges as they are assessing the legality of legislative decisions and the highest and final judicial instance of record.

In order to keep themselves from these external influences judicial officers may become socially isolated. The next section explains the nature of social isolation experienced by judicial officers.

\subsection{Social Isolation}

Social isolation has been identified as a major problem faced by judicial officers due to their professional obligations [6]. When judges are under public scrutiny they are being observed and studied carefully. Their private life is also coming under the media scrutiny which creates pressure. Media interest in the work of judiciary and judges' places under the spotlight on many occasions [21]. Therefore, Judges must maintain a certain demeanour. A participant stated:

"I feel I am always on guard and watched. We have to be very careful about what we talk, behave, wear. People make judgements about the entire judiciary based on our behaviour. I had to give up on my friendships specially with lawyers and some relatives are angry for not attending their family gatherings" (District court judge, 14 years). 
Health risks are associated with having a small social network. Infrequent contact with network members and a lack of social network diversity, low participation in social activities, particularly volunteering and religious attendance are threats to mental health wellbeing [22]. When individuals limit their social interactions, they are susceptible to mental stress. Judicial isolation is an inherent part of the role, judges must play in society. It can seriously diminish a judge's intellectual and social abilities [6]. A participant stated:

"It is very stressful sometimes to keep yourself away from the things you like to do. But we have no option. I would like to actively participate in social activities and religious activities, but we can't attend those public gatherings in our jurisdictions" (Supreme court judge, 34 years).

Spouse and the children of judges must maintain a certain demeanour. Therefore, they also experience social isolation to a certain degree. They must be careful when building relationships and interacting with members of society. Litigants of the cases may attempt approaching them with ulterior motives. Therefore, the spouse and children of judges cannot freely interact with outsiders and build new social connections like other individuals do. A participant stated:

"Not only us husband and children also have to be very careful with the people they associate. Like us they also must be selective with people they associate. Because people who want to approach us might try approach us through them (High court judge, 21 years).

Social isolation experienced by female judicial officers is distinguishable from male judicial officers. Female judicial officers were finding it difficult to find a partner or get married after they joined judiciary. Consequently, they experienced relatively higher social isolation. A participant stated:

"It is difficult to get married after joining the judiciary, men think that we would rule them like we do in courts and run a petticoat government at home" (Magistrate, 9 years).

In most Asian cultures a women's career considered to be subservient to that of males. Women who engage in professions such as military or legal considered tough and powerful. Therefore, men may show reluctance to get married to women in such professions. Majority of unmarried female judicial officers mentioned that their life is confined to the office and home.

Pressure stemming from social isolation can be worsen when judges have to deal with workplace conflicts. The next section explains the interpersonal conflict between judges and lawyers.

\subsection{Interpersonal Conflict between Lawyers and Judges}

Judges have found conflict between the bench and the bar is demanding. Incompatibility of interests and approaches towards litigants and lawsuits leads to interpersonal conflicts between judges and lawyers. The interest of the judge is to conclude a lawsuit as quickly as possible. Avoid the backlog of cases, the public confidence towards the judiciary, finish the workload and save people from 
suffering and spending unnecessarily on lawsuits are the primary concerns of the judge. The motives of lawyers are financial because litigants must pay them per appearance in courts. The majority of lawyers prefer to drag the case out for as long as possible. Consequently, it increases the backlog of cases, the workload and mental stress for the judge. A participant stated:

"Most of the litigants are financially weak, we feel sorry for them, but lawyers want to drag cases as much as possible. So, they repeat the same question, waste time in cross examination, ask for further dates unnecessarily. It creates a back$\log$ and increase our workload. That is very stressfup' (District court judge, 16 years).

Judicial officers mentioned when they realized that lawyers are unnecessarily dragging the cross examinations and asking for further dates' judges intervened and directly spoke to litigants and solved the lawsuit. Consequently, it led to creation of workplace enemies. Judicial officers mentioned when they intrude into cross examinations and refuse to agree to further dates unless there are unavoidable circumstances and also when lawyers realize judge is strict and firm, they display aggression by writing petitions against the judge to the ministry or trying to transfer them. A participant stated:

"When I realize the lawyer deliberately drag the case I directly speak to litigants. Therefore, lawyers hate me. They have written lots of petitions against me to the chief justice. They have tried to transfer me to another station..." (Court of appeal judge, 32 years).

As demonstrated above, stress for judges deriving from work overload, political influences, social isolation and interpersonal conflict between judges and lawyers can negatively affect their performance and influence of gruesome evidence can exacerbate their stress. The next section explains the influence of gruesome evidence on judges.

\subsection{Influence of Gruesome Evidence}

Serving on the bench can be a stressful experience. Certain trials involve murder, sexual assault, child abuse and traumatic events that may physically and emotionally distress for judges. Gruesome crime scene and autopsy photographs are regularly introduced in both criminal and civil trials [23]. Murder inquests, graphic photographs of injury or death and verbal evidence play an important role in a legal case. So, judges are exposed to and handle graphic evidence on daily basis. Continual exposure to shocking, graphic, emotion-laden and painful evidence can have a negative emotional impact and numerous physical and psychological effects such as loss of appetite, insomnia and mental stress [24]. A participant stated:

"Murder inquests induce huge stress, before a every seen visit I go to toilet several times, I lose the appetite. I don't know how people can kill someone so brutally. Murder inquest is the most horrible part of my job..." (Magistrate, 8 years). 
Judges handle domestic violence, murder, rape, child neglect and abuse, divorce and child custody, mental illness, sentencing. At the extreme, these stressors, together with the traumatic nature of the material that judges have to consider, can result in vicarious trauma [24]. A participant stated:

"I experience stress specially when I preside at child abuse cases, rape cases. They make me sad and depressed" (District court judge, 12 years).

The decision-making process, specifically for crimes such as murder, child abuse and sexual assault had the repercussions on a personal level for judges and produced increased levels of emotional stress. Twenty one out of fifty-four judges expressed how gruesome evidence had a negative emotional impact on them.

\section{Implications of Research}

Implications of the present study has discussed under theoretical contributions and practical implications.

\subsection{Theoretical Contribution}

This study adds to the existing literature on job demands in several ways. Firstly, this study contributes to the job demands and resource theory by conducting a profession-specific job demands study. There is an absence of systematic studies which identify the job demands experienced by specific professional groups [14] [10]. Identification of specific job demands perceived by particular members of the occupation group assist in the development of job demands literature and work-related stress theories [14]. This lacuna was addressed by conducting the study among judicial officers in Sri Lanka and identifying job demands such as political influence, social isolation which has not been usually discussed in the job demands literature and work stress literature.

Secondly, this study adds to the political dimension of job demands literature. This addition also is considered as an original contribution of the study. Work stress can be aggravated by political influences. However, political influences have not been identified as a job demand in the job demands-resources literature. It may be due to the exclusivity of this dimension. Experience of political intervention is different from other professional occupations such as academics, doctors and engineers as they are not vulnerable to direct political influences [5]. Therefore, this finding addressed the lacuna of absence of profession-specific job demands and added to the political dimension of job demands literature.

Finally, this study suggested that experience of particular job demands may vary based on gender. Female judicial officers perceived social isolation in terms of reduced potential of marriage mobility while male judges perceived in terms of lack of social interaction and entertainment. In Eastern countries women's academic aptitude and economic independence are not predictors of marriage and women's career considered to be subservient to that of males [25]. Therefore, it has been found that women with higher education attainment and so- 
cioeconomic resources such as financial security, social status marry later, never be able to get married or have fewer children [26].

\subsection{Practical Implications}

Judiciary is an integral part of any society. This study clearly identified that judges are experiencing stress from factors such as political influence, social isolation, effects of gruesome evidence, work overload and interpersonal conflict between lawyers and judges. Consequently this may affect mental wellbeing of judges and negatively impact their cognitive abilities and rational decision making skills [27]. Therefore, it is imperative for policy developers and practitioners of the judicial working environment to understand and formulate intervention strategies to alleviate these problems from judicial working environment. Findings of this study can be transferred to the similar judicial environments.

\subsection{Areas for Future Research}

While the literature has discussed about the effect of isolated factors of stress on employee wellbeing, however, the interaction of stressors and ripple effect on employees have rarely been discussed. For example, stress created by work overload can be compounded by political influences and social isolation. Consequently, effect of such a composition of stressors can be detrimental and may not be limited to above mentioned health effects. This opens up a debate to explore the compounding effects of stressors and its effects on occupational functioning.

\section{Conclusion}

The judiciary is an important element of the justice system. Judicial officers have a vital role that can prove extremely demanding due to various sources of stress. Judicial overload, political influence, social isolation, effects of gruesome evidence and interpersonal conflicts between lawyers and judges generate immense stress to judicial officers. As mentioned above it is important that researchers understand and control these potential sources because undoubtedly these stressors may impede their occupational duties. Intervention strategies should focus on alleviating judicial job demands and creating conducive working environment for judges.

\section{Conflicts of Interest}

The author declares no conflicts of interest regarding the publication of this paper.

\section{References}

[1] Bakker, A.B. and Bal, P.M. (2010) Weekly Work Engagement and Performance: A Study among Starting Teachers. Journal of Occupational and Organizational Psychology, 83, 189-206. https://doi.org/10.1348/096317909X402596

[2] Bakker, A., Hakanen, J., Demerouti, E. and Xanthopoulou, D. (2007) Job Resources 
Boost Work Engagement, Particularly When Job Demands Are High. Journal of Educational Psychology, 99, 274-284. https://doi.org/10.1037/0022-0663.99.2.274

[3] Salanova, M. and Schaufeli, W. (2008) A Cross-National Study of Work Engagement as a Mediator between Job Resources and Proactive Behaviour. The International Journal of Human Resource Management, 19, 116-131. https://doi.org/10.1080/09585190701763982

[4] Chamberlain, J. and Miller, K. (2009) Evidence of Secondary Traumatic Stress, Safety Concerns, and Burnout among a Homogeneous Group of Judges in a Single Jurisdiction. The Journal of the American Academy of Psychiatry and the Law, 37, 214-224.

[5] Chamberlain, J., Miller, M.K., Flores, D., Bornstein, B. and Richardson, J.T. (2011) Judges' Perspectives on Stress and Safety in the Courtroom: An Exploratory Study. SSRN Electronic Journal, 45, 76-89.

[6] Zimmerman, I.M. (2000) Isolation in the Judicial Career. Judges Writing Journals. A Personal Perspective, 36, 2000.

[7] Tsai, F.-J. and Chan, C.-C. (2010) Occupational Stress and Burnout of Judges and Procurators. International Archives of Occupational Environmental Health, 83, 133-142. https://doi.org/10.1007/s00420-009-0454-1

[8] Bakker, A.B. and Demerouti, E. (2016) Job Demands-Resources Theory: Taking Stock and Looking Forward. Journal of Occupational Health Psychology, 22, 273-285. https://doi.org/10.1037/ocp0000056

[9] Mette, J., Velasco, G.M., Preisser, A.M., Harth, V. and Mache, S. (2018) Linking Quantitative Demands to Offshore Wind Workers' Stress: Do Personal and Job Resources Matter? A Structural Equation Modelling Approach. BMC Public Health, 18, 934. https://doi.org/10.1186/s12889-018-5808-8

[10] Schaufeli, W.B. (2017) Applying the Job Demands-Resources Model: A "How to" Guide to Measuring and Tackling Work Engagement and Burnout. Organizational Dynamics, 46, 120-132. https://doi.org/10.1016/j.orgdyn.2017.04.008

[11] Demerouti, E., Bakker, A.B. and Fried, Y. (2012) Work Orientations in the Job Demands-Resources Model. Journal of Managerial Psychology, 27, 557-575. https://doi.org/10.1108/02683941211252428

[12] Airila, A., Hakanen, J.J., Schaufeli, W.B., Luukkonen, R., Punsksllio, A. and Lusa, S. (2014) Are Job and Personal Resources Associated with Work Ability 10 Years Later ? The Mediating Role of Work Engagement. Work \& Stress, 28, 87-105. https://doi.org/10.1080/02678373.2013.872208

[13] Demerouti, E. and Bakker, A.B. (2011) The Job Demands-Resources Model: Challenges for Future Research. SAIIP. South African Journal of Industrial Psychology, 37, a974. https://doi.org/10.4102/sajip.v37i2.974

[14] Schaufeli, W.B. andTaris, T.W. (2014) A Critical Review of the Job Demands-Resources Model: Implications for Improving Work and Health. In: Bauer, G.F. and Hämmig, O., Eds., Bridging Occupational, Organizational and Public Health: A Transdisciplinary Approach, Springer, Berlin, 43-68. https://doi.org/10.1007/978-94-007-5640-3

[15] Clarke, V. and Braun, V. (2013) Teaching Thematic Analysis: Overcoming Challenges and Developing Strategies for Effective Learning. The Psychologist, 26, 120-123.

[16] Abeyratne, R. (2015) Rethinking Judicial Independence in India and Sri Lanka. Asian Journal of Comparative Law, 10, 99-135. https://doi.org/10.1017/asjcl.2015.6

[17] Robertson, G. (2014) Judicial Independence: Some Recent Problems (Thematic Pa- 
pers No 4 June 2014). International Bar Association Human Rights Institute.

[18] International Bar Association (IBA) (2009) Justice in Retreat: A Report on the Independence of the Legal Profession and the Rule of Law in Sri Lanka. http://www.ibanet.org/Document/Default.aspx?DocumentUid=c7793247-1498-409f $-83 \mathrm{~d} 0-75 \mathrm{~b} 3 \mathrm{dfd} 107 \mathrm{c} 7$

[19] International Bar Association's Human Rights Institute (IBAHRI) (2012) Authority without Accountability: The Crisis of Impunity in Sri Lanka. http://www.refworld.org/pdfid/50ae365b2.pdf

[20] International Bar Association (IBA) (2013) A Crisis of Legitimacy: The Impeachment of Chief Justice Bandaranayake and the Erosion of the Rule of Law in Sri Lanka (Vol. 2009).

[21] Lee, H.P. (2015) Of Courts and Judges: Under the Spotlight, in the Limelight and Seeing the Light. Monash University Law Review, 41, 283-298.

[22] Waite, L.J. and Cornwell, E.Y. (2009) Perceived Social Disconnectedness, Isolation, and Health among Older Adults. Journal of Health and Social Behavior, 50, 31-48. https://doi.org/10.1177/002214650905000103

[23] Woolf, C.F. (2011) A Study of Stress from High Profile Trials among Jurors and Court Staff. Institute for Court Management Court Executive Development Program 2010-2011 Phase III Project, (May).

[24] Kendall, C. (2011) Report on Psychological Distress and Depression in the Legal Profession.

https://www.lawsocietywa.asn.au/wp-content/uploads/2015/08/Report-on-psycholo gical-distress-and-depression-in-the-legal-profession.pdf

[25] Raymo, J.M., Park, H., Xie, Y. and Yeung, W. (2015) Marriage and Family in East Asia: Continuity and Change. Annual Review of Sociology, 41, 471-492. https://doi.org/10.1146/annurev-soc-073014-112428

[26] Glen, H. and Elder, J. (2018) Appearance and Education in Marriage Mobility. American Sociological Review, 34, 519-533. https://doi.org/10.2307/2091961

[27] Azharudeen, N.T. and Arulrajah, A.A. (2018) The Relationships among Emotional Demand, Job Demand, Emotional Exhaustion and Turnover Intention. International Business Research, 11, 8-18. https://doi.org/10.5539/ibr.v11n11p8 